\title{
UPAYA PENINGKATAN PERILAKU HIDUP BERSIH DAN SEHAT PADA ANAK USIA SEKOLAH
}

\author{
Serri Hutahaean ${ }^{1}$ dan Nourmayansa Vidya Anggraini ${ }^{2}$ \\ ${ }^{1}$ Program Studi Sarjana Keperawatan, Universitas Pembangunan Nasional Veteran Jakarta \\ Email: serrihthyn@upnvj.ac.id \\ ${ }^{2}$ Program Studi Sarjana Keperawatan, Universitas Pembangunan Nasional Veteran Jakarta \\ Email: nourmayansa@upnvj.ac.id
}

\begin{abstract}
Clean and Healthy Living Behavior regarding environmental hygiene affects health. Various kinds of diseases can be avoided by implementing a Clean and Healthy Lifestyle. The purpose of this community service activity is to provide counseling to improve clean and healthy living behavior. The target is school-age children. The method of implementing this community service activity is counseling or health education to school-age children and teaching handwashing practices with the right steps. Schoolage children are encouraged to demonstrate appropriate handwashing practices with the right steps. In addition, a demonstration or demonstration of how to wash hands was also carried out. Counseling was carried out on an aggregate of 30 school-age children in the area of RT04 RW04, Susukan Subdistrict, Subdistrict. The results of the counseling showed that there was an increase in the level of knowledge and attitudes of children before and after education regarding clean and healthy living behavior. Knowledge in children increased from 30\% to $90 \%$ have good knowledge after health counseling. Meanwhile, good attitude increased from 10\% to 93.33\%. Actions before and after education got the same results, namely 40\%. Judging from the behavior of children who have not done PHBS, especially for hand washing which is still lacking, children's habits in choosing unhealthy snacks are still a lot and the behavior of littering still needs to be re-educated. Based on the results of this community service activity, it is expected that school-age children will continue to carry out PHBS in their daily lives. In addition, it is necessary to support parents and the surrounding environment in carrying out PHBS habits in order to achieve health for schoolage children and their families as well as the environment.
\end{abstract}

Keywords: Behavior, clean life, healthy life, school children

\begin{abstract}
ABSTRAK
Perilaku Hidup Bersih dan Sehat menyangkut kebersihan lingkungan berpengaruh terhadap kesehatan. Berbagai macam penyakit dapat dihindari dengan melaksanakan Perilaku Hidup Bersih dan Sehat. Tujuan kegiatan pengabdian kepada masyarakat ini adalah memberikan penyuluhan untuk meningkatkan perilaku hidup bersih dan sehat. Sasarannya adalah anak usia sekolah. Metode pelaksanaan kegiatan pengabdian kepada masyarakat ini adalah penyuluhan atau pendidikan kesehatan kepada anak usia sekolah dan mengajarkan praktik cuci tangan dengan langkah yang benar. Anak usia sekolah diminat untuk melakukan redemonstrasi praktik cuci tangan sesusia dnegan langkah yang benar. Selain itu juga dilakukan peragaan atau demonstrasi cara cuci tangan. Penyuluhan dilakukan terhadap agregat anak usia sekolah sebanyak 30 Orang di wilayah RT04 RW04 Kelurahan Susukan Kecamatan. Hasil penyuluhan didapatkan bahwa terjadi peningkatan tingkat pengetahuan dan sikap anak sebelum dan sesudah dilakukan edukasi mengenai perilaku hidup bersih dan sehat. Pengetahuan pada anak meningkat dari $30 \%$ menjadi 90\% memiliki pengetahuan yang baik setelah dilakukan penyuluhan kesehatan. Sedangkan sikap yang baik meningkat dari 10\% menjadi 93,33\%. Tindakan saat sebelum dan setelah edukasi mendapat hasil yang sama yaitu 40\%. Dilihat dari perilaku anak yang belum melakukan PHBS khususnya untuk tindakan cuci tangan yang masih kurang, kebiasaan anak dalam memilih jajanan yang tidak sehat masih banyak serta perilaku membuang sampah sembarangan masih perlu dilakukan edukasi kembali. Berdasarkan hasil kegiatan pengabdian masyarakat ini diharapkan anak usia sekolah terus melakukan PHBS dalam kehidupan sehari-hari. Selain itu perlu dukungan orang tua dan lingkungan sekitar dalam melakukan kebiasaan PHBS supaya tercapai kesehatan pada anak usia sekolah dan keluarga juga lingkungan.
\end{abstract}

Kata kunci : Perilaku, hidup bersih, sehat, anak sekolah

\section{PENDAHULUAN}

Kehidupan manusia tidak lepas dari kesehatan yang merupakan bagian yang penting. Latar belakang manusia berbeda-beda, namun kesehatan tetap yang utama dan integral dalam kehiduapnnya. Kesehatan manusia dipengaruhi oleh beberapa faktor. Dalam suatu komunitas ditemukan berbagai kelompok khusus. Salah satu kelompok di komunitas yang rentan adalah kelompok anak usia sekolah. Hal yang perlu dilakukan dalam meningkatkan pola hidup sehat khususnya pada anak usia sekolah adalah dengan melakukan berbagai kegiatan yang dapat 
menciptakan pola hidup sehat pada anak usia sekolah. Menurut Adriani \& Wirjatmadi (2012), definisi anak sekolah merupakan anak yang berada pada usia sekolah yaitu antara 6-12 tahun.

Tiga pilar utama kebijakan Indonesia Sehat 2010 adalah perilaku sehat, lingkungan sehat, dan pelayanan kesehatan yang berkualitas. Dalam mencapai visi Indonesia Sehat 2010 pemerintah telah menetapkan Sistem Kesehatan Nasional (SKN) dengan Keputusan Menteri Kesehatan No.131/Menkes/SK/II/2004. Subsistem Pemberdayaan Masyarakat merupakan bagian dari SKN. Perilaku Hidup Bersih dan Sehat 2010 (PHBS 2010) merupakan bagian dari Kebijakan Nasional Promosi Kesehatan (Promkes). Hal ini guna untuk mendukung upaya peningkatan perilaku sehat ditetapkan visi nasional Promkes sesuai Keputusan Menteri Kesehatan RI. No.1193/MENKES/SK/X/2004. Keputusan Menteri Kesehatan RI. No.1114/Menkes/SK/VIII/2005 (Eva Yanti, 2010) telah ditetapkan dalam pelaksanaan program Promosi kesehatan di daerah.

Perilaku Hidup Bersih Dan Sehat (PHBS) sudah umum diketahui oleh masyarakat. Hal ini berkaitan dengan perilaku seseorang yang berkaitan dengan kebersihan lingkungan dan dapat berpengaruh terhadap kesehatannya. Beberapa penyakit dihindari dengan penerapan PHBS, diantaranya adalah diare, DBD, flu burung, atau pun covid-19 yang sedang menjadi masalah pandemic di dunia yang muncul sejak akhir tahun 2019. Banyak faktor yang mendukung PHBD, diantaranya adalah kesehatan lingkungan yang terdapat di sekitar tempat tinggal individu masingmasing. Pencegahan penyakit di berbagai tatanan kehidupan memerlukan penerapan PHBS. Beberapa tatanan itu diantaranya adalah tatanan rumah tangga individu ataupun di tatanan rumah sakit.

Menurut Cahyadi (2006) bahwa makanan jajanan yang diperdagangkan sering ditemukan berisiko terhadap kesehatan. Hal ini dikarenakan penanganannya yang tidak higienis, sehingga makanan jajanan tersebut terkontaminasi mikrobia. Selain itu juga bisa terkontaminasi bahan tambahan pangan (BTP). Kebiasaan jajan yang dilakukan oleh anak dan makanan yang dikonsumsi oleh anak ini saling berkaitan terhadap masalah kesehatan anak. Makanan jajanan ini merupakan makanan yang diperjualbelikan oleh pedagang kaki lima ataupun pedagang lainnya yang terdapat di keramaian umum. Makanan jajanan ini bisa langsung dikonsumsi tanpa pengolahan lebih lanjut. Menurut Khomsan (2003) bahwa makanan jajanan tersebug seringkali tidak ada persiapan secara higienis ataupun menggunakan bahan pengawet atau pewarna yang berbahaya bagi tubuh.

Dalam kasus komunitas yang ada di wilayah RT04 RW04 Kelurahan Susukan Kecamatan Ciracas, Jakarta Timur didapatkan hasil data bahwa terdapat Jumlah KK yang anggota keluarganya perokok ada 4 KK (40\%), semua yang merokok adalah berjenis kelamin laki - laki sedangkan wanita tidak ada yang merokok. Penyakit yang diderita oleh masyarakat dalam 1 bulan yaitu sakit gigi sebanyak 2 orang, hipertensi sebanyak 2 orang, sariawan 1 orang, dan amandel 1 orang. Pada anak usia sekolah dalam periode 3 bulan terakhir sakit gigi 2 orang, sariawan 1 orang, amandel 1 orang, muntah - muntah 2 orang, diare 2 orang dan demam 1 orang. Kebiasaan mencuci tangan pada kelompok anak usia sekolah $40 \%$ hanya melakukan cuci tangan setelah melakukan Kegiatan saja, $60 \%$ anak usia sekolah selalu mencuci tangan setiap sebelum dan sesudah melakukan tindakan. Kebiasaan mengkonsumsi jajanan pada agregat anak usia sekolah $50 \%$ masih biasa mengkonsumsi jajanan warung dan 50\% anak usia sekolah biasa mengkonsumsi jajanan buatan rumah. Pengetahuan warga mengenai jajanan yang berbahaya, $70 \%$ cukup mengetahui, $20 \%$ mengetahui, dan $10 \%$ tidak tahu. 
Masyarakat Indonesia sebagian besar belum membudayakan perilaku cuci tangan dalam kehidupan sehari-hari. Mereka masih belum memahami tata cara cuci tangan yang benar. Hal ini dibuktikan dengan masih ditemukan di kehidupan masyarakat mencuci tangan hanya menggunakan dengan air tanpa menggunakan sabun dan tanpa langkah yang benar. Berdasarkan fenoneman ini, maka cuci tangan untuk mencapai kebersihan tangan merupakan prioritas yang tinggi. Namun hal ini sering disepelekan. Kebiasaan cuci tangan merupakan suatu kebiasaan yang muncul sejak kecil dan merupakan pembiasaan dari lingkungan. Anak usia sekolah perlu diberikan promosi kesehatan supaya terjadi perubahan sikap dan perilaku, khususnya terkait perilaku hidup bersih dan sehat. Menurut Batanoa (2008), dengan diberikan promosi kesehatan terkait mencuci tangan yang benar maka diharapkan anak akan memberikan contoh terhadap orang tuanya untuk menerapkan perilaku cuci tangan yang benar. PHBS cuci tangan dengan menggunakan sabun harus digalakkan sejak dini pada anak-anak untuk mencegah penyebaran virus (Darmalaksana et al., 2020). Penerapan sejak dini ini karena anak usia sekolah mempunyai daya tahan tubuh yang rendah sehingga rawan terhadap penyakit (Tabi'in, 2020). Selain cuci tangan kebiasaan anak dalam memilih jajanan yang tidak sehat masih banyak dan menaruh sampah pada tempatnya perlu diedukai kembali karena bagian dari perilaku hidup bersih dan sehat. Maka dari data yang telah didapatkan saya mengambil kegiatan tentang PHBS khususnya cara cuci tangan yang benar.

PHBS bukan merupakan istilah asing di dalam masyarakat. Kepanjangan PHBS yakni Perilaku Hidup Bersih dan Sehat. Hal ini berkaitan dengan perilaku seseorang yang menyangkut kebersihan lingkungan yang dapat berpengaruh terhadap kesehatannya. Berbagai penyakit dapat dihindari dengan pelaksanan PHBS, diantaranya diare, DBD, flu burung, atau pun covid 19 yang sedang terjadi di dunia ini sebagai pandemi. Salah satu faktor yang mendukung PHBS adalah kesehatan lingkungan yang ada di sekitar tempat tinggal individu. Beberapa tatanan itu diantaranya adalah tatanan rumah tangga sebagai tempat tinggal individu ataupun di tatanan rumah sakit sebagai tempat yang rawan dalam penyebaran penyakit. Menurut Aulina (2018) bahwa anak usia sekolah perlu pengawasan dalam melaksanakan PHSB dikarenakan anak sering makan tanpa cuci tangan terlebih dahulu. Hal inilah yang menyebabkan perlunya pengawasan yang ekstra sehingga diharapkan akan muncul kebiasaan baik dalam PHBS (Aulina, 2018). Anak yang sehat maka pertumbuhan fisik dan psikososialnyanya akan tumbuh dan berkembang sesua dengan usianya (Julianti, 2018). Edukasi PHBS dilakukan pada agregat anak usia sekolah di wilayah RT04 RW04 Susukan Ciracas Jakarta Timur.

Dalam kasus komunitas yang ada di wilayat RT04 RW04 Kelurahan Susukan Kecamatan Ciracas, Jakarta Timur didapatkan hasil data bahwa Jumlah KK yang anggota keluarganya perokok ada 4 KK (40\%), semua yang merokok adalah berjenis kelamin laki - laki sedangkan wanita tidak ada yang merokok. Penyakit yang diderita oleh masyarakat dalam 1 bulan yaitu sakit gigi sebanyak 2 orang, hipertensi sebanyak 2 orang, sariawan 1 orang, dan amandel 1 orang. Pada anak usia sekolah dalam periode 3 bulan terakhir sakit gigi 2 orang, sariawan 1 orang, amandel 1 orang, muntah muntah 2 orang, diare 2 orang dan demam 1 orang.

Kebiasaan mencuci tangan pada agregat anak usia sekolah $40 \%$ hanya melakukan cuci tangan setelah melakukan kegiatan saja, $60 \%$ anak usia sekolah selalu mencuci tangan setiap sebelum dan sesudah melakukan tindakan. Kebiasaan mengkonsumsi jajanan pada agregat anak usia sekolah 50\% masih biasa mengkonsumsi jajanan warung dan 50\% anak usia sekolah biasa mengkonsumsi jajanan buatan rumah. Pengetahuan warga mengenai jajanan yang berbahaya, $70 \%$ cukup mengetahui, $20 \%$ mengetahui, dan $10 \%$ tidak tahu. 


\section{METODE PELAKSANAAN PKM}

Metode yang dilakukan dalam kegiatan pengabdian masyarakat ini adalah memberikan penyuluhan atau pendidikan kesehatan. Sasaran dari penyuluhan atau pendidikan kesehaatn ini adalah anak usia sekolah. Penyuluhan atau pendidikan kesehatan dilakukan dengan metode ceramah dan peragaan atau demonstrasi.

Terdapat beberapa tahapan dalam persiapan kegiatan penyuluhan. Tahapan tersebut adalah pembuatan pre-planning, persiapan penyajian seperti materi presentasi, media penyuluhan, atau alat demonstrasi. Pemberitahuan tentang penyuluhan kesehatan dilakukan pada tanggal 13 Maret 2021 pada agregat anak usia sekolah di RT04 RW04 Kelurahan Susukan Kecamatan Ciracas. Media dalam penyuluhan ini adalah Power Point, Leaflet, dan Video.

Penyuluhan tentang Perilaku Hidup Bersih dan Sehat (PHBS) pada agregat anak usia sekolah di wilayah RT04 RW04 Kelurahan Susukan Kecamatan Ciracas sebanyak 30 Orang. Waktu dan hari yang telah ditetapkan dalam pelaksanaan penyuluhan adalah pada hari Rabu, tanggal 13 Maret 2021 jam 10.00 WIB.

\section{HASIL DAN PEMBAHASAN}

Tahapan dalam kegiatan penyuluhan kesehatan dibagi menjadi 3 tahap yaitu:

a. Tahap perkenalan dan penggalian pengetahuan

Sebelum memulai acara penyuluh memberikan kuesioner pre test untuk mengetahui tingkat pengetahuan, sikap, dan perilaku tentang perilaku hidup bersih dan sehat (PHBS). Pada pembukaan acara, pembawa acara mengucapkan salam dan memperkenalkan diri kepada anak usia sekolah yang hadir saat penyuluhan kesehatan. Sebelum materi disampaikan, penyuluh memberitahukan tujuan dan maksud dari kegiatan penyuluhan kesehatan tersebut. Kemudian penyaji memberikan pemaparan materi. Penyaji menanyakan terlebih dahulu tentang masalah pengetahuan perilaku hidup bersih dan sehat (PHBS) sebelum materi disampaikan kepada peserta.

\section{b. Tahap Penyajian Materi}

Saat dilakukan penyajian materi oleh tim penyaji, anak usia sekolah memperhatikan dengan seksama walaupun terkadang ada yang tidak fokus. Penyajian materi sesuai dengan materi penyuluhan yang telah dibuat oleh tim pengabdian masyarakat. Setelah penyajian materi selesai, kemudian penyaji memutar video cuci tangan 6 langkah yang benar dan selanjutnya mendemonstrasikannya. Setelah edukasi yang sudah diberikan, penyaji menanyakan apakah ada pertanyaan dari partisipan.

\section{c. Tahap Evaluasi}

Materi Setelah materi tersajikan dengan baik dan lancar, anak usia sekolah paham dengan materi yang disajikan, penyuluh memberikan pertanyaan pada peserta anggota pendidikan kesehatan untuk mengevaluasi dan mengetahui tingkat pengetahuan keluarga setelah penyajian materi yang berupa: singkatan dari PHBS, manfaat cuci tangan, cara mencuci tangan 6 langkah, memilih jajanan sehat, 3 macam tempat sampah, prinsip membuang sampah. Setelah itu memberikan post tes berupa kuesioner pengetahuan, sikap, dan perilaku tentang PHBS.

\section{1) Struktur}

Pelaksanaan kegiatan penyuluhan kepada anak usia sekolah di wilayah RT04 RW04 Kelurahan Susukan Kecamatan Ciracas, melibatkan penyuluh selaku pemberi informasi kepada peserta penyuluhan mengenai pendidikan kesehatan Perilaku Hidup Bersih dan Sehat. Kegiatan ini dapat berlangsung dengan adanya kerjasama antara penyuluh dengan peserta penyuluhan. 


\section{2) Proses}

Pelaksanaan penyuluhan berjalan sesuai dengan rencana, tertib dan teratur. Kehadiran anak usia sekolah tidak sesuai dengan yang diharapkan, yang hadir hanya 7 anak dan 3 anak berhalangan hadir. Dengan antusiasnya anak dapat menjawab pertanyaan yang diajukan oleh penyaji dan dapat mempraktikkan bersama sama cara mencuci tangan 6 langkah dengan benar.

Berikut adalah hasil pre test dan post test dari partisipan edukasi:

A. Pengetahuan PHBS

Kuesioner pengetahuan ada 10 pertanyaan yang diajukan kepada partisipan sebelum dan sesudah edukasi diberikan. Adapun hasil dari kuesioner terdapat pada Tabel 1.

\section{Tabel 1}

Pengetahuan PHBS pada Agregat Anak Usia Sekolah Tahun 2021 (n=30)

\begin{tabular}{lllll}
\hline Pengetahuan & \multicolumn{2}{c}{ Pre test } & \multicolumn{2}{c}{ Post test } \\
& $\mathrm{N}$ & $\%$ & $\mathrm{~N}$ & $\%$ \\
\hline Baik & 9 & 30 & 27 & 90 \\
Buruk & 21 & 70 & 3 & 10 \\
Total & 30 & 100 & 30 & 100 \\
\hline
\end{tabular}

Dari Tabel 1 dapat dilihat bahwa terdapat peningkatan tingkat pengetahuan sebelum dan sesudah dilakukan edukasi mengenai perilaku hidup bersih dan sehat. Sebelum Edukasi didapatkan pengetahuan baik 30\% dan meningkat setelah edukasi menjadi $90 \%$. Sementara pengetahuan buruk sebelum edukasi $70 \%$ dan setelah edukasi menurun menjadi $10 \%$.

\section{B. Sikap PHBS}

Kuesioner sikap ada 10 pertanyaan yang diajukan kepada partisipan sebelum dan sesudah edukasi diberikan. Adapun hasil dari kuesioner terdapat pada Tabel 2.

\section{Tabel 2}

Sikap PHBS pada Agregat Anak Usia Sekolah Tahun 2021 (n=30)

\begin{tabular}{lllll}
\hline Sikap & \multicolumn{2}{l}{ Pre test } & \multicolumn{2}{c}{ Post test } \\
& $\mathrm{N}$ & $\%$ & $\mathrm{~N}$ & $\%$ \\
\hline Baik & 10 & 33,33 & 28 & 93,33 \\
Buruk & 20 & 66,67 & 2 & 6,67 \\
Total & 30 & 100 & 30 & 100 \\
\hline
\end{tabular}

Dari Tabel 2 dapat dilihat terdapat peningkatan tingkat sikap sebelum dan sesudah dilakukan edukasi mengenai perilaku hidup bersih dan sehat. Sebelum edukasi didapatkan sikap baik 33,33\% dan meningkat setelah edukasi menjadi $93,33 \%$. Sementara sikap buruk sebelum edukasi 66,67\% dan setelah edukasi menurun menjadi $6,67 \%$.

\section{Tindakan PHBS}

Kuesioner tindakan ada 7 pertanyaan yang diajukan kepada partisipan sebelum dan sesudah edukasi diberikan. Adapun hasil dari kuesioner terdapat pada Tabel 3. 


\section{Tabel 3}

Tindakan PHBS pada Agregat Anak Usia Sekolah Tahun 2021 (n=30)

\begin{tabular}{lllll}
\hline Tindakan & \multicolumn{2}{c}{ Pre test } & \multicolumn{2}{c}{ Post test } \\
& $\mathrm{N}$ & $\%$ & $\mathrm{~N}$ & $\%$ \\
\hline Baik & 12 & 40 & 12 & 40 \\
Buruk & 18 & 60 & 18 & 60 \\
Total & 30 & 100 & 30 & 100 \\
\hline
\end{tabular}

Dari Tabel 3 dapat dilihat tidak ada peningkatan Tindakan sebelum dan sesudah dilakukan edukasi mengenai perilaku hidup bersih dan sehat. Tindakan saat sebelum edukasi dan setelah edukasi mendapat hasil yang sama yaitu $40 \%$. Tindakan buruk sebelum edukasi dan setelah edukasi juga sama yaitu $60 \%$.

Tiga pilar utama kebijakan Indonesia Sehat 2010 adalah perilaku sehat, lingkungan sehat, dan pelayanan kesehatan yang berkualitas. Dalam mencapai visi Indonesia Sehat 2010 pemerintah telah menetapkan Sistem Kesehatan Nasional (SKN) dengan Keputusan Menteri Kesehatan No.131/Menkes/SK/II/2004. Subsistem Pemberdayaan Masyarakat merupakan bagian dari SKN. Perilaku Hidup Bersih dan Sehat 2010 (PHBS 2010) merupakan bagian dari Kebijakan Nasional Promosi Kesehatan (Promkes). Hal ini guna untuk mendukung upaya peningkatan perilaku sehat ditetapkan visi nasional Promkes sesuai Keputusan Menteri Kesehatan RI. No.1193/MENKES/SK/X/2004. Keputusan Menteri Kesehatan RI. No.1114/Menkes/SK/VIII/2005 (Eva Yanti, 2010) telah ditetapkan dalam pelaksanaan program Promosi kesehatan di daerah.

Perilaku Hidup Bersih Dan Sehat (PHBS) sudah umum diketahui oleh masyarakat. Hal ini berkaitan dengan perilaku seseorang yang berkaitan dengan kebersihan lingkungan dan dapat berpengaruh terhadap kesehatannya. Beberapa penyakit dihindari dengan penerapan PHBS, diantaranya adalah diare, DBD, flu burung, atau pun covid-19 yang sedang menjadi masalah pandemic di dunia yang muncul sejak akhir tahun 2019. Banyak faktor yang mendukung PHBD, diantaranya adalah kesehatan lingkungan yang terdapat di sekitar tempat tinggal individu masingmasing. Pencegahan penyakit di berbagai tatanan kehidupan memerlukan penerapan PHBS. Beberapa tatanan itu diantaranya adalah tatanan rumah tangga individu ataupun di tatanan rumah sakit.

Masyarakat Indonesia sebagian besar belum membudayakan perilaku cuci tangan dalam kehidupan sehari-hari. Mereka masih belum memahami tata cara cuci tangan yang benar. Hal ini dibuktikan dengan masih ditemukan di kehidupan masyarakat mencuci tangan hanya menggunakan dengan air tanpa menggunakan sabun dan tanpa langkah yang benar. Berdasarkan fenoneman ini, maka cuci tangan untuk mencapai kebersihan tangan merupakan prioritas yang tinggi. Namun hal ini sering disepelekan. Kebiasaan cuci tangan merupakan suatu kebiasaan yang muncul sejak kecil dan merupakan pembiasaan dari lingkungan. Anak usia sekolah perlu diberikan promosi kesehatan supaya terjadi perubahan sikap dan perilaku, khususnya terkait perilaku hidup bersih dan sehat. Menurut Batanoa (2008), dengan diberikan promosi kesehatan terkait mencuci tangan yang benar maka diharapkan anak akan memberikan contoh terhadap orang tuanya untuk menerapkan perilaku cuci tangan yang benar.

\section{KESIMPULAN DAN SARAN}

Penyuluhan yang dilakukan pada pada agregat anak usia sekolah di wilayah RT04 RW04 Kelurahan Susukan Kecamatan Ciracas didapatkan hasil bahwa hasil pengetahuan sebelum dan 
sesudah dilakukan penyuluhan mengalami peningkatan pengetahuan. Sikap anak sebelum mengikuti penyuluhan dengan sesudah mengikuti penyuluhan juga mengalami peningkatan.

Tindakan anak dalam melakukan PHBS sebelum mengikuti penyuluhan dengan sesudah mengikuti penyuluhan mengalami tidak ada mengalami peningkatan ataupun penurunan. Hal ini kemungkinan diakibatkan perubahan perilaku yang masih memerlukan waktu untuk merubah perilaku anak dalam melakukan PHBS dengan penuh kesadaran. Anak cenderung bermain-main, hal ini merupakan anak dalam masa eksploratif (Tabi’in, 2019).

Dilihat dari perilaku anak yang belum melakukan PHBS khususnya dalam melakukan cuci tangan, kebiasaan anak dalam memilih jajanan yang tidak sehat masih banyak juga, serta perilaku membuang sampah pada tempatnya yang masih kurang sehingga disarankan perlunya dilakukan edukasi kembali karena bagian dari perilaku hidup bersih dan sehat.

\section{REFERENSI}

Adriani \& Wirjatmadi. (2012). Peranan gizi dalam siklus kehidupan. Kencana.

Khomsan, A. (2003). Pangan dan gizi untuk kesehatan. Raja Grafindo Persada.

Aulina, C. N. (2018). Peningkatan kesehatan anak usia dini dengan penerapan perilaku hidup bersih dan sehat (PHBS) di TK Kecamatan Candi Sidoarjo. AKSIOLOGIYA: Jurnal Pengabdian Kepada Masyarakat, 3(1), 50. https://doi.org/10.30651/aks.v3i1.1480.

Cahyadi, W. (2006). Bahan tambahan pangan. Bumi Aksara.

Darmalaksana, W., Hambali, R. Y. A., \& Masrur, A. (2020). Analisis pembelajaran online masa WFH pandemic covid-19 sebagai tantangan pemimpin digital abad 21. Karya tulis ilmiah (KTI) masa work from home (WFH) covid-19 UIN Sunan Gunung Djati Bandung, 1-12.

Julianti, R. (2018). Pelaksanaan perilaku hidup bersih dan sehat (PHBS) di lingkungan sekolah. Jurnal Ilmiah Potensial, 3.

Keputusan Menteri Kesehatan Republik Indonesia no 131/Menkes/SK/II/2004 Tentang Sistem Kesehatan Nasional

Tabi'in, A. 2020. Perilaku hidup bersih dan sehat (PHBS) pada anak usia dini sebagai upaya pencegahan covid 19. Jea (Jurnal Edukasi Aud) Pendidikan Islam Anak Usia Dini Universitas Islam Negeri Antasari Banjarmasin. doi: 10.18592/jea.v6i1.3620, 2020.

Tabi'in, A. (2019). Implementation of STEAM method (science, technology, engineering, arts and mathematics) for early childhood developing in kindergarten mutiaraparadise pekalongan. doi:10.23917/ecrj.v2i2.9903. 